\title{
Social Inequalities and ICT Teacher's In-Service Training
}

\author{
Panagiotis Giavrimis \\ University of the Aegean, Mytilene, GREECE \\ Department of Sociology
}

Received: 28 May 2020 - Accepted: 19 July 2020 - Published Online: 14 October 2020

\begin{abstract}
The purpose of this paper is to present the teachers' views about their in-service training in ICT. This research is part of a more general research aimed at exploring the educational needs of teachers and the application of ICT in the education system and their impact on the teaching, learning and cognitive process. The sample of this research consists of 162 teachers working in primary schools in Northern Greece. Of these, 70 (43.2\%) were men and 92 (56.8\%) were women. The results of the research show that teachers emphasize the functioning of the institution of education in ICT as a tool for implementing educational policy of the dominant social groups, but also their reflection on European education policy. They also express the need for continuing education, while differing in its role in removing educational inequalities.
\end{abstract}

Keywords: ICT, in-service training, social inequalities.

\section{Introduction}

ICT is the new cognitive tool in modern society that differentiates both the social structure and the life of social subjects (Robins \& Webster, 2002: 3-9). ICT are approached as a system of values and actions that can penetrate any social reality, influencing both the way society is organized and the way of thinking (Rannerberg et al., 2009) and expanding social inequalities (Feather, 1994). According to the OECD, those who do not have access to ICT and have no skills in them, face a new inequality, that of the digital divide. There is, therefore, a need for the future school to develop social subjects with critical thinking, creativity, flexibility, responsibility and cooperation skills, self-regulated learning and making critical decisions under pressure, ambiguity, and uncertainty (Raptis \& Raptis, 2002). At the same time, ICT is considered in the modern globalized educational environment as a complex process involving individuals, processes, ideas, means, and organizational functions aiming at the analysis and management of learning (Egea, 2013; Serwaes \& Heinderyck, 2002; Solomonidou, 2006; Witte \& Mannon, 2010)). The development and changes that are taking place make it necessary to continuously train individuals to avoid social exclusion from social, economic and political activity (OECD, 1996).

\section{Sociological approaches of ICT and in-service training}

Structural-functional analysis point out that the primary goal is the maintenance and perpetuation of the social system, highlighting the unifying role of common values and common ideas and perceptions in building social consensus (Stolley, 2005). It is argued that all sections of

(C) Authors. Terms and conditions of Creative Commons Attribution 4.0 International (CC BY 4.0) apply. Correspondence: Panagiotis Giavrimis, University of the Aegean, Department of Sociology, Mytilene, GREECE. E-mail: giavrimis@soc.aegean.gr. 
society, even the poorest, contribute in some way to maintaining order and stability in society. Social stratification exists in all societies, while education uses meritocracy as a mechanism to motivate and secure the best position in the social division of labor for the most capable (Ferrante, 2011). The theory of functioning is at the core of modernity, where through capitalist ideology and market practice it seeks to lead to economic, social, cultural, political, and technological development (Weane, 1989). Structural - functional analysis recognize that if a part of the social system is transformed, then the other parts of it are adjusted to balance. ICT, in this context, by transforming the social system, is shaping the new conditions for occupying social positions. Accessibility, information management, social skills and skills in ICT are the meritocratic criteria for hierarchies, social stratification and the reproduction of social constants.

- Teachers emphasize the functioning of the institution of education in ICT as a tool for pursuing an educational policy of the dominant social groups, but also their reflection on European education policy;

- Teachers express the need for continuing education, while differing in its role in removing educational inequalities;

- While increased funding, teachers considered necessary as means of better quality upgrading of ICT training.

The postmodern social division of labor requires the ease and convenience of managing and producing information, applications, and materials from a social subject (broader process in terms of literacy), and the deeper acquisition of concepts and capabilities (Rapporteur, 2006), which revises the didactic-pedagogical reality of the school and the curriculum. Pedagogy and teaching science deal with the introduction of ICT in education, describing the problems (Law et al., 2008; Pelgrum, 2001; Slaouti \& Barton, 2007) and the effects on learning (Kafai et al., 2002; Rumpagaporn \& Darmawan, 2007) highlighting a technocratic-positivist approach. At the same time, state intervention to ensure more effective teaching is intense (Bromley \& Apple, 1998). Paraphrasing what Castells (1998) said about work, we can say that the teacher has never been more vulnerable to the organization of the teaching practice, as he is isolated in a malleable network, which he himself does not know, which is exactly where he is placed, as it is constantly modified. The teacher is called upon to transform his knowledge and skills, to acquire information literacy (Bikos, 1989) in order to enhance the teaching practice, but also to be able to meet the increased and changing needs of young social subjects. The above transmits a lot of pressure to teachers and highlights the project of their training. In such an environment of liquidity and change, the teacher therefore needs education and training (Elliot, 1977) adapted to the new social conditions, to acquire a higher level of skills, for global education, and to establish "lifelong" education (Vergidis, 1993; Bagakis, 2000). ICT alone does not automatically modernize a school unit. This essentially means that training is mainly a function of the identified needs of the teachers themselves, which are determined by the pre-existing basic education, by their work and by the educational system in which they work. Contributing to this is the existence of a specific training policy, which in the context of a broader educational policy which promotes the academic, professional and personal development of the teacher (Athanasoula-Reppa et al., 1999).

Here we must point out that the old contract that was a relationship agreement was based on teacher-centered teaching and student "devotion". The new contract in education tends to be more and more short-term, based mainly on the processing and transformation of new social data and the development of critical thinking and the individual's ability to constructively compose the multitude of stimuli and experiences, while "dedication" In the old sense has been eliminated (DiMaggio et al., 2001). Education as a mechanism for influencing and sensitizing teachers (Witte \& Mannon, 2010), seeks to reshape the meanings that teachers give to the educational process and to establish new interpretations of the criteria of socialization and selection and the importance of ICT in them. 
3. ICT in-service teacher training programs in Greece

Over the last few decades, there has been a growing teacher training activity in ICT, which is presented as a parameter of a more general reform effort for education. Of course, any reform is inevitably linked to the political ideology and programmatic planning of each government. In the mid-1990s, the first programs for the training of teachers in ICT (Jimoyiannis, \& Komis, 2007) began, while in the following years, with the co-financing of EE, programs such as "ODYSSEY" (1996-2001) were implemented. "In-school training" (2000-2001), the program "Training of Primary and Secondary Education Teachers in Basic ICT Skills in Education" (Level 1) (2001-2005) (Fragouli \& Hammond, 2007) and "Training of teachers for the use and application of ICT in teaching practice" (Level B) (2007-2013) (see "Information and Cooperation Portal of Level B Training"), which continues. From the programs in the training of ICT that were implemented, difficulties emerged related to the teaching techniques used by the trainers, but also the use of ICT in the school context (Giavrimis et al., 2012; Karamanis et al., 2000; Minaidi \& Hlapanis, 2005) and positive points regarding the change in the level of knowledge and skills of teachers (Zagouras, 2005) and the use of ICT in teaching practice (Demetriadis et al., 2003; Tsitouridou \& Vryzas, 2004).

The purpose of this paper is to present the views of teachers on their training in ICT and their correlation with inequalities in the education system.

\section{Method \\ 4.1 Sample}

The sample of this research consists of 162 teachers working in primary schools in Northern Greece. Of these, 70 (43.2\%) were men and 92 (56.8\%) were women. Regarding their age, 7 (4.3\%) were under 30 years old, 69 (42.6\%) belong to the age group 31-40 years, 81 (50\%) belong to the age group 41-50 years and $5(3.1 \%)$ in the age group 51-60 years. Of the additional demographic data collected, 17 people (10.5\%) are single, 138 (85.1\%) are married and 4 (2.5\%) are divorced and $3(1.9 \%)$ are cohabiting. The average years of service of the teachers of the sample is 14.14 (T.A. $=6.72$ ), with an average of 13 years, a lower value of one year and a maximum value of 30 years. Regarding the years since the acquisition of the teacher's degree, it seems that the average is 20.35 years (T.A. $=6.28$ ), the average is 21 years, the lowest value is two years and the maximum value is 33 years.

\subsection{Researching tool}

An improvised questionnaire on teacher training in ICT was used to conduct the research. It includes a total of 80 questions. The questions are divided into five topics: (a) Reasons of attendance: Includes questions related to the reasons for attending an ICT program, (b) Satisfaction and teaching methods from the ICT program: Includes questions related to teacher satisfaction from the ICT program they attended and the methods and techniques used by the instructors, (c) Knowledge in ICT after the program: Includes questions related to the skills acquired by the teachers after the end of the program, (d) Attitudes about ICT after the program: Includes questions which refer to the attitude of teachers towards ICT and their inclusion in their daily and educational practice, and (e) Sociological approaches: It includes questions of sociological content, which concern the position of the school in the social becoming. This paper presents questions related to the third and fifth thematic sections. 


\section{Findings}

Table 1 and Figure 1 show that the teachers of our research: (1) point out the importance of continuing education for the management of educational reality, (2) attach great importance to funding and the changes that entail in pedagogical-teaching practice, (3) emphasize (at least $50 \%$ of them) the contribution of education to the elimination of social inequalities, (4) have a negative view (at least 50\%) on the fact that ICT alleviates educational inequalities, the common European policy on education and training replacing in-person training with distance learning, and (5) differentiate opinions with statistical significance [multivariate criterion of variance analysis with repetitive measurements: Hotelling's Trace, $F(2,160)=63.2, p<0.001$, $\eta 2$ $=0,70$, primary function: $\mathrm{F}(1,161)=383.44, \mathrm{p}<0.001, \eta 2=0.70]$ (Figure 1 ), where they consider continuing education as very important in relation to the others. Issues, on the second level of significance, are related to funding for the elimination of social inequalities, while they have the most negative view of the ICT assistance in the elimination of educational inequalities, European policy and distance education.

Table 1. Funding, training, ICT and inequalities

\begin{tabular}{|c|c|c|c|c|c|}
\hline \multirow{2}{*}{ Questions } & \multirow{2}{*}{ Median } & \multicolumn{4}{|c|}{ Quadrants } \\
\hline & & 10 & 25 & 50 & 75 \\
\hline $\begin{array}{c}\text { The continuing education of teachers helps in the daily life of } \\
\text { the school (Q. 1) }\end{array}$ & 5.00 & 2.00 & 4.00 & 5.00 & 5.00 \\
\hline $\begin{array}{c}\text { Adequate school funding affects the quality of ICT education } \\
\text { provided (Q. 2) }\end{array}$ & 4.00 & 3.00 & 4.00 & 4.00 & 4.00 \\
\hline $\begin{array}{l}\text { The increase in funding for school ICT should be combined } \\
\text { with pedagogical changes in the education system (Q. 3). }\end{array}$ & 4.00 & 3.00 & 4.00 & 4.00 & 4.00 \\
\hline ICT education can bridge social inequalities (Q. 4) & 4.00 & 2.00 & 2.00 & 4.00 & 5.00 \\
\hline $\begin{array}{c}\text { Training in new technologies in education will alleviate } \\
\text { educational inequalities (Q. 5) }\end{array}$ & 3.00 & 1.00 & 2.00 & 3.00 & 4.00 \\
\hline $\begin{array}{l}\text { I am in favor of a common European policy for teacher training } \\
\text { (Q. 6) }\end{array}$ & 3.00 & 1.00 & 1.00 & 3.00 & 4.00 \\
\hline $\begin{array}{c}\text { Distance learning is just as effective as in-person teaching (Q. } \\
7) .\end{array}$ & 3.00 & 1.00 & 1.00 & 3.00 & 4.00 \\
\hline
\end{tabular}

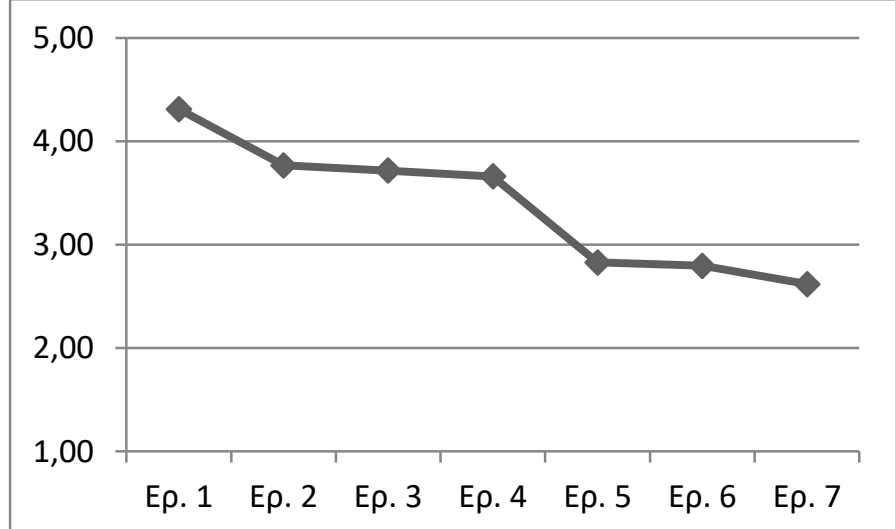

Figure 1. Hierarchical ranking

The influence of gender on the above questions does not seem to be significant and the view of men and women does not differ [Er. 1: Mann-Whitney $U=3062, Z=-0.609, p=0.542$, Fig. 2: Mann-Whitney $U=3065, Z=-0.724, p=0.469$ ), Fig. 3: Mann-Whitney $U=3141, Z=-$ 0.393, $\mathrm{p}=0.694$, Fig. 4: Mann-Whitney $\mathrm{U}=2985, \mathrm{Z}=-0.827, \mathrm{p}=0.408$, Fig. 5: Mann-Whitney $\mathrm{U}=2815, \mathrm{Z}=-1.433, \mathrm{p}=0.152$, Fig. 6: Mann-Whitney $\mathrm{U}=2957, \mathrm{Z}=-0.938, \mathrm{p}=0.348$, Fig. 7: Mann-Whitney $\mathrm{U}=2661, \mathrm{Z}=-1.978, \mathrm{p}=0.480$ ], while the years of service are not correlated with 
their views on education and inequalities [Er. 1: $\mathrm{r}=-0.004, \mathrm{p}=0.958, \mathrm{Q} .2: \mathrm{r}=-0.021, \mathrm{p}=0.793$, Q. 3: $r=-0.066, p=0.404, Q .4: r=0.076, p=0.337, Q .5: r=-0.234, p=0.543, Q .6: r=-0.074$, $\mathrm{p}=0.346, \mathrm{Q} \cdot 7: \mathrm{r}=-0.106, \mathrm{p}=0.178]$.

More than $75 \%$ of teachers appear to have a negative view of the help that ICT education can offer in terms of improving their basic education, scientific training and self-esteem, which does not appear to meet the new educational needs. The opinion of $25 \%$ of teachers is in the middle of the scale. In relation to ICT, they state that training helps a lot in acquiring skills, while about $25 \%$ are negative in this regard as well.

Table 2. Training in ICT and professional development

\begin{tabular}{cccccc}
\hline Training in ICT helps: & \multirow{2}{*}{ Median } & \multicolumn{4}{c}{ Quadrants } \\
& & 10 & 25 & 50 & 75 \\
\hline Improving your basic education & 2.00 & 2.00 & 2.00 & 2.00 & 3.00 \\
In response to new educational needs & 2.00 & 2.00 & 2.00 & 2.00 & 3.00 \\
To increase your scientific training & 2.00 & 1.00 & 2.00 & 2.00 & 3.00 \\
In increasing your professional self-esteem & 2.00 & 1.00 & 2.00 & 2.00 & 3.00 \\
In the acquisition of skills in ICT. & 3.00 & 1.00 & 2.00 & 3.00 & 3.00 \\
\hline
\end{tabular}

Referring to the factors that influence the design of ICT training programs, our research teachers cite the requirements of capital and the economic system as the most important. The use of the variable criterion of analysis of variance with repeated measurements found statistically significant differences in the specific views [Hotelling's Trace, $F(2,160)=31.12, p$ $<0.001$, h2 $=0.28]$. The comparison for the primary function was also statistically significant: $\mathrm{F}$ $(1,161)=64.00, p<0.001, \eta 2=0.28$. The averages of the 3 questions are shown in Figure 1 in ascending order. From the above data, it can be seen that teachers significantly differentiate between the importance of influencing social institutions in the structure of training programs. In more detail, teachers believe that social demands do not significantly affect the decisions made in the preparation of training programs. The most important role is of the demands of capital and the economic system, while the political choices of the states are also a lever of influence.

Table 3. Sources of influence of training programs

\begin{tabular}{ccccc}
\hline \multirow{2}{*}{ Training programs are designed based on } & \multirow{2}{*}{ Median } & \multicolumn{3}{c}{ Quadrants } \\
& & 25 & 50 & 75 \\
\hline Capital requirements and the financial system (Q. 8) & 4.00 & 3.00 & 4.00 & 5.00 \\
Political choices of states (Q. 9) & 4.00 & 3.00 & 4.00 & 4.00 \\
Social requirements (Q. 10) & 3.00 & 2.00 & 3.00 & 4.00 \\
\hline
\end{tabular}

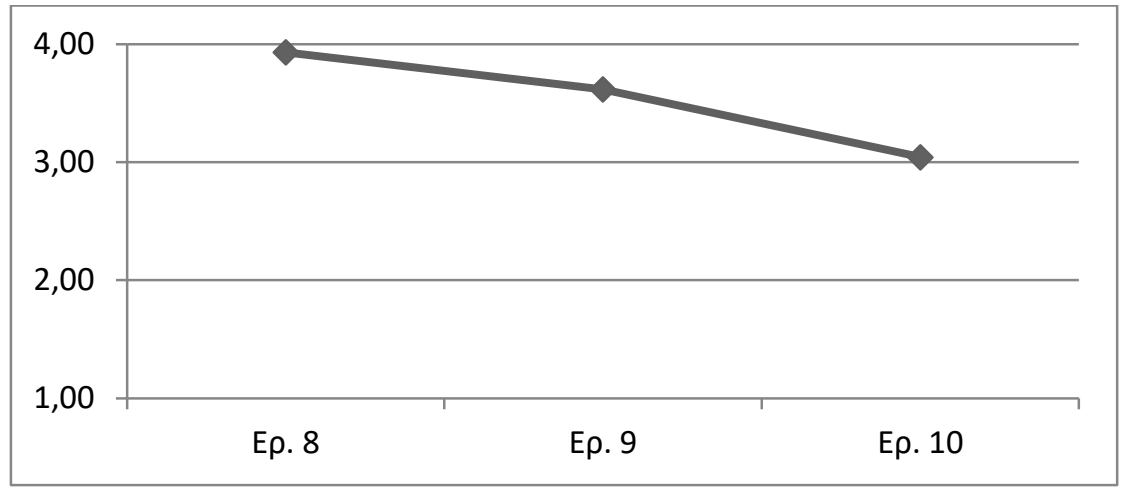

Figure 2. Hierarchical ranking of training impact sources 


\section{Discussion}

The teacher and his insights into the growing inequalities in the educational context are a powerful influencing factor (Blackledge \& Hunt, 2000). The research teachers give us meaning in their own role in the educational system, but also in the educational system itself in dealing with educational reality and in removing social and educational inequalities, indirectly emphasizing the functional role of education in providing equal opportunities through meritocratic processes that favor social mobility and alleviate social inequalities. The majority of our research teachers refer to the positive role that education can play in removing social exclusion, we would say in an ideal correlation, because at the micro level of ICT applications in education it seems that they have a more negative view. Social inequalities and their correlations with the outcomes of education have been studied in recent decades, highlighting several interpretive examples (Blackledge \& Hunt, 2000; Lamnias, 2001; Fragoudaki, 1985), but also the role of intermediate variables, such as gender, social class, nationality and race (Romero \& Margolis, 2005).

In the globalized and changing postmodern environment, the continuous training of teachers (Saitis, 2005) and especially in ICT is necessary. It is no coincidence, then, that strategies for implementing educational policy make teacher upgrading one of their top priorities (Bagakis, 2005). The teachers of our research interpret the institution of education as reproductive, where their contents and orientation are determined by the dominant social groups, which can impose their own ideological and political positions as another form of "symbolic violence". European education policy is perceived, formally, negatively by teachers, indicating their opposition to mechanisms of pressure and homogenization of education, while broader social requirements do not play such an important role in the decisions taken to prepare training programs. Teachers give meaning to the institution of education as a mechanism for influencing the relative autonomy of the teacher, for the benefit of the dominant ideas and opinions (Mavrogiorgos, 1999).

The results of the research show that teachers point out the importance of continuing education, while rejecting distance education. Funding in education, but also in the introduction of ICT, plays a dominant role in upgrading the quality of education, but also in changing pedagogical-teaching practices, according to their views. Similar findings have been found in other research, highlighting the need to support teachers through training and changing culture and practices in education (Giavrimis \& Giossi, 2011), but also to increase the financial resources available to upgrade the teacher's project (Spyropoulou et al., 2004). The consequence of the above is the expression of a negative to ambivalent view by several teachers who believe that school cannot remove inequalities in education, not even with the use of new cognitive tools (ICT). This is supported by their views on the inadequate training of ICT teachers, which does not contribute to the improvement of basic education, scientific training, self-esteem and the full development of ICT skills, and does not appear to meet the new educational needs. their. Similar results have been found in Greek and international space (Drent \& Meelissen, 2008; Zagoura, 2005. Galanouli et al., 2004; Jimoyiannis, \& Komis, 2006; 2007; Karagiorgi, \& Charalambous, 2006). Education for all and alleviation of social inequalities are among the issues of the postmodern era, but both the functioning of education and the way ICT is introduced into education do not help eliminate educational inequalities. Education reproduces social inequalities by failing to provide a socially differentiated quality of learning, insisting on instrumental analyzes of technocratic elements and quantified cognitive data. As Althusser (1999) states, education functions as an ideological mechanism of repression, reproducing inequalities in the distribution of social roles and the labor market and normalizing students' performance in school and ICT (Blackledge \& Hunt, 2000). These views do not seem to differ from either gender or years of service in our research.

In conclusion, teachers emphasize the functioning of the institution of education in ICT as a tool for pursuing an educational policy of the dominant social groups, but also their reflection on European education policy. They express the need for continuing education, while 
differing in its role in removing educational inequalities. The insufficient fulfillment of the objectives of the training in ICT by state bodies advocates the above views of the teachers. There is, therefore, indirectly the educational project of building a functional training program that will keep up the pace with the new cognitive tools provided in the post-modern era, while increased funding is considered necessary as means of better quality upgrading of ICT training. Dominant elements, however, we think are the decentralization of educational decisions, the participation of teachers in decision-making for the implementation of ICT in education and for the implementation of their training, but mainly the change of culture and interpretive patterns used by teachers in relation to their operation within the educational system.

\section{Acknowledgements}

This research did not receive any specific grant from funding agencies in the public commercial, or not-for-profit sectors.

The author declares no competing interests.

\section{References}

Althusser, L. (1999). Positions (Trans. X. Giataganas). Athens: Themelio

Athanasoula - Repa, A., Anthopoulou, S., Katsoulakis, S., \& Mavrogiorgos G. (1999). Human Resources Management. Patras: E.A.P.

Bagakis, G. (Ed.) (2000). Optional educational programs in school education. Athens: Routledge.

Bagakis, G. (Ed.) (2005). Training and professional development of the teacher. Athens, Routledge

Blackledge, D., \& Hunt, B. (2000). Sociology of Education (trans. M. Deligianni). Athens: Metaixmio.

Bromley, H., \& Apple M. W. (Eds.) (1998). Education/technology/power: Educational computing as a social practice. Albany: State University of New York Press.

Castells, M. (1998). La societe en reseaux. Paris: Fayard.

Demetriadis, S., Barbas, A., Molohides, A., Palaigeorgiou, G., Psillos, D., Vlahavas, I., Tsoukalas, I., \& Pombortsis, A. (2003). Cultures in negotiation: Teachers' acceptance/resistance attitudes considering the infusion of technology into schools. Computers \& Education, 41, 19-37.

DiMaggio, P., Hargittai, E., Neuman, W. R., \& Robinson, J. P. (2001). Social implications of the Internet. Annual Review of Sociology, 27, 307-336.

Drent, M., \& Meelissen, M. (2008). Which factors obstruct or stimulate teacher educators to use ICT innovatively? Computers \& Education, 51, 187-199.

Egea, O. (2013). Technology, pedagogy and education: Neoliberalism, education and the integration of ICT in schools. A critical reading. Technology, Pedagogy and Education, 11, 1-17.

Elliot, A. J. (1997). Integrating the "classic" and "contemporary" approaches to achievement motivation: A hierarchical model of approach and avoidance achievement motivation. In M. L. Maehr \& P. R. Pintrich (Eds.), Advances in motivation and achievement (pp. 143-179). Greenwich: JAL.

Feather, J. (1994). The information society. A study of continuity and change. London: Library Association Publishing.

Ferrante, J. (2011). Seeing sociology: An introduction. Wadsworth: Cengage Learning. 
Fragkouli, E., \& Hammond, M. (2007). Issues in developing programmes to support teachers of philology in using information and communications technologies in Greek schools: a case study. Journal of In-Service Education, 33(4), 463-477.

Fragoudaki, A. (1985). Sociology of education. Theories of social inequality in school. Athens: Papazisi.

Galanouli, D., Murphy, C., \& Gardner, J. (2004). Teachers' perceptions of the effectiveness of ICTcompetence training. Computers \& Education, 43, 63-79.

Giavrimis, P., Giossi, S., \& Papastamatis, A. (2011). Teachers' attitudes towards training in ICT: A critical approach. Quality Assurance in Education, 19(3), 283-296.

Giavrimis, P., Valkanos, E., Anastasiou, A., \& Siskos, A. (2012). Teachers' perspectives on information and communications technology training programmes. International Journal of Academic Research in Progressive Education and Development, 1(3), 135-150.

Jimoyiannis, A., \& Komis, V. (2006). Exploring secondary education teachers' attitudes and beliefs towards ICT adoption in education. Themes in Education, 7(2), 181-204.

Jimoyiannis, A., \& Komis, V. (2007). Examining teachers' beliefs about ICT in education: Implications of a teacher preparation programme. Teacher Development: An International Journal of Teachers' Professional Development, 11(2), 149-173.

Kafai, Y. B., Fishman, B. J, Bruckman, A. S., \& Rockman, S. (2002). Models of educational computing home: New frontiers for research on technology in learning. Educational Technology Review, 1O(2), $52-68$.

Karagiorgi, Y., \& Charalambous, K. (2006). ICT In-service training and school practices: In search for the impact. Journal of Education for Teaching: International research and pedagogy, 32(4), 395411.

Karamanis, M., Politis, P., Roussos, P., \& Tsaousis, C. (2000). Review of teacher education within the ULYSSES project. In B. Earl (Ed.), Technologies of Information and Communication Technologies in Education. Athens: New Technologies.

Law, N., Pelgrum, W., \& Plomp, T. (2008). Pedagogy and ICT use. Hong Kong: Springer.

Mavrogiorgos, G. (1999). Training teachers and educational policy in Greece. In A. Reppas, S., \& S. Anthopoulou Katsoulaki (Ed.), Human Resource Management (pp. 123-131). Patra: CRD.

Minaidi, A., \& Hlapanis, G. (2005). Pedagogical obstacles in teacher training information and communication technology. Technology, Pedagogy and Education, 14(2), 241-254.

Mpikos, K. (1989). Technology and education. In Proceedings of the Third International Conference Pedagogical Orthodox Academy of Crete (pp. 311-318). Athens: Pedagogical Society of Greece.

OECD (1996). Evaluating and reforming education systems. Paris: Organisation for Economic Cooperation and Development.

Pelgrum, W. (2001). Obstacles to the integration of ICT in education: Results from a worldwide educational assessment. Computers and Education, 37, 163-178.

Rannenberg, K., Royer D., \& Deuker, A. (Eds.) (2009). The future of identity in the information society: Challenges and opportunities. Berlin: Springer.

Rapporteur, S. M. (2006). ICT fluency and high schools. Washington: The National Academies Press.

Raptis A., \& Rapti A., (2002). Learning and teaching in the information age. Athens.

Robins K., \& Webster F. (2002). The era of technoculture (K. Metaxa, Trans.). Kastaniotis. In M. Romero \& E. Margolis (2005). The Blackwell companion to social inequalities. Oxford: Blackwell Publishing Ltd.

Rumpagaporn, M., \& Darmawan, G. (2007). Students' critical thinking skills in a Thai ICT schools pilot project. International Education Journal, 8(2), 125-132.

Saitis, X. (2005). Organization and administration of education. Athens. 
Serwaes, J., \& Heinderyck, F. (2002). The 'new' ICTs environment in Europe: closing or widening the gaps? Telematics and Informatics, 19, 91-115.

Slaouti, D., \& Barton, A. (2007). Opportunities for practice and development: newly qualified teachers and the use of information and communication technologies in teaching foreign languages in English secondary school contexts. Journal of In-service Education, 33(4), 19.

Solomonidou, C. (2006). New trends in educational technology. Athens: Routledge.

Spyropoulou, D., Kontaris, Ch, Antonakaki, T., \& Chala, Ch. (2004). Financial resources in education. PI. Recovery on 02/01/2014 by http://www.pischools.gr/download/programs/erevnes/ax poiot xar prot deft ekp/poiot ekp erevn/s 437 466.pdf.

Stolley, K. S. (2005). The basics of sociology. West port: Greenwood Press.

Tsitouridou, M., \& Vryzas, K. (2004). The prospect of integrating ICT into the education of young children: the views of Greek early childhood teach. European Journal of Teacher Education, 27(1), 2945.

Tzimogiannis, A., \& Earl, B., (2004). Attitudes and perceptions of secondary school teachers on the implementation of ICT in their teaching. In M. Grigoriadis, A. Raptis, S. Vosniadou \& C. Hunter (Eds.), ICT in Education (pp. 165-176). Athens.

Tzimopoulos, N. (2003). Teacher training on new technologies. Information and communications. The case of introductory training programs of Cyclades. Patra: CRD.

Vergidis, D. (1993). Neoliberal education policy and teacher training. Modern Education, 69, 43-49.

Weane, C. (1989). The theory and scholarship of Talcott Parsons to 1951. Cambridge: Cambridge University Press.

Witte, J. C., \& Mannon, S. E. (2010). The internet and social inequalities. London: Routledge.

Zagouras, C. (2005). The training of teachers to use ICT in education. The experience of ICT. Athens: Ellinika Grammata. 
P. Giavrimis - Social Inequalities and ICT Teacher's In-Service Training

C O A $\mathrm{s}$ 